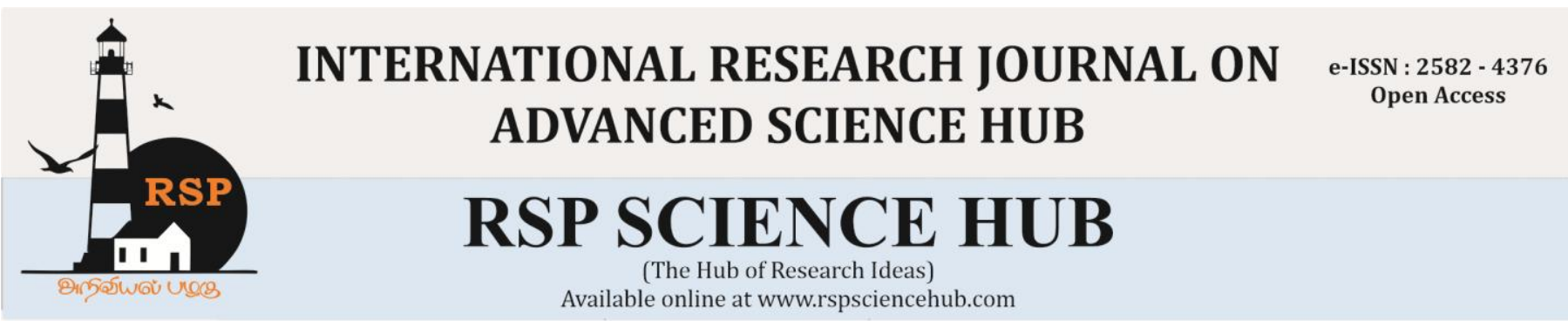

\title{
Mini Solar Towers using Fresnel Lenses
}

Kavin. $D^{1}$, Sai Santhosh. $A^{2}$, Vasant ${ }^{3}$, Mr.S.Bharath ${ }^{4}$

${ }^{1,2,3}$ Student, Department of Electrical and Electronics Engineering, SNS College of Technology, Coimbatore-35.

${ }^{4}$ Assistant Professor, Department of Electrical and Electronics Engineering, SNS College of Technology, Coimbatore-35.

kavinsangamesh@gmail.com ${ }^{1}$.saisanthosh3099@gmail.com ${ }^{2}$,vasantselvam8887@gmail.com ${ }^{3}$, bharathbhadri@gmail.com ${ }^{4}$

\begin{abstract}
This paper aims to give an overview of the solar tower technology and its consequences along with a new concept of mini solar towers using Fresnel lens. Fresnel lens are used to concentrate the solar radiation falling on the aperture to a particular point. It contributes to update the economic status and technical status of molten salt solar tower technology. It has aspired to explain the solar power tower with an overview of energy, renewable energy, solar energy, solar photovoltaic, solar thermal and Fresnel Lenses.
\end{abstract}

Key Words-ST-solar tower, Fresnel lens, concentrated collectors

\section{Introduction}

The energy demand is growing rapidly. To meet out the demand, electricity generation also increases. Everyone started to move towards Renewable resources like solar, wind, hydro etc,. Because the sources like Coal, Petroleum is at the edge of their extinction. "Energy can neither be Created nor Destroyed whereas it can be transferred from one form to another.

\section{Source of Energy:}

There are two sources of energy,
A) Renewable source
B) Non-Renewable Source

\subsection{Renewable sources of Energy:}

In the past decades, the consumption of nonrenewable sources of energy has caused more fatal damage to environment than any other human activity. Electrical Energy generated from fossil fuels such as coal and oil has led to increased concentrations of greenhouse gases in the atmosphere which in turn led to so much problems being faced now-a-days such as global warming and ozone depletion. Vehicular air pollution has also been a major problem. Therefore, renewable sources of energy have become relevant and very important to present days. Renewable sources, such as the sun and wind, can never be bankrupted. Most of the renewable sources of energy are likely nonpolluting and considered clean though biomass, a renewable source, is a major polluter indoors. Renewable energy sources include the sun, water, wind, fuel wood, agricultural residue, and animal dung. Energy obtained from the sun is known as solar energy. 


\subsection{Solar Photovoltaic:}

Photovoltaic (PV) is the method of converting light energy into direct current using semiconductors which exhibits the Photovoltaic effect. A group of solar cells connected in a specific arrangement to produce the desired output voltage and current by means of solar panels. Materials used in photovoltaic's are monocrystalline, polycrystalline, cadmium telluride, amorphous silicon gallium selenide /sulfide and copper indium.

\subsection{Solar Thermal:}

Solar Thermal Energy is an innovative and developing Technology for harnessing thermal (heat) energy from the sun. Solar Thermal Collectors are classified based on the temperature rating as follow: a) Low, b) Medium and c) High temperature collectors. Flat plates are Lowtemperature collectors generally used to heat swimming pools which is less than 80 degree Celsius. Medium-temperature collectors are also usually flat plates but are used for heating water or air for residential and commercial use over temperature of 200 degree Celsius. Hightemperature collectors concentrate sunlight using mirrors or lenses or Heliostats and are generally used for electric power production at a temperature of 400 degree Celsius.

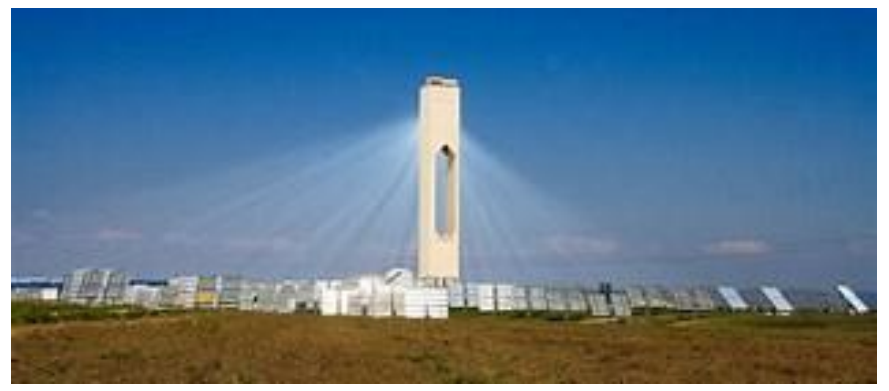

Figure.1. Solar tower with heliostats

\section{History of Solar Towers:}

Solar towers generates electricity from heat energy from sun's radiation by focusing concentrated radiation on a tower-mounted heat receiver. This system uses a thousands of sun tracking mirrors called heliostats to reflect the incident sun rays onto the receiver. These plants are mostly suited for utility-scale applications in the range of 10 to
$100 \mathrm{MW}$. The Solar tower technology has been the subject of research and development in the United States since the 1970s.[1-4]

In the past two decades, solar towers are less commercial than parabolic trough systems, numerous component and system experiments have been fielded around the world, demonstrating the economic potential and engineering feasibility of the technology. Since the early 1980s, the solar towers had been situated in Italy, Russia, Japan, Germany, France, Spain and the United States.

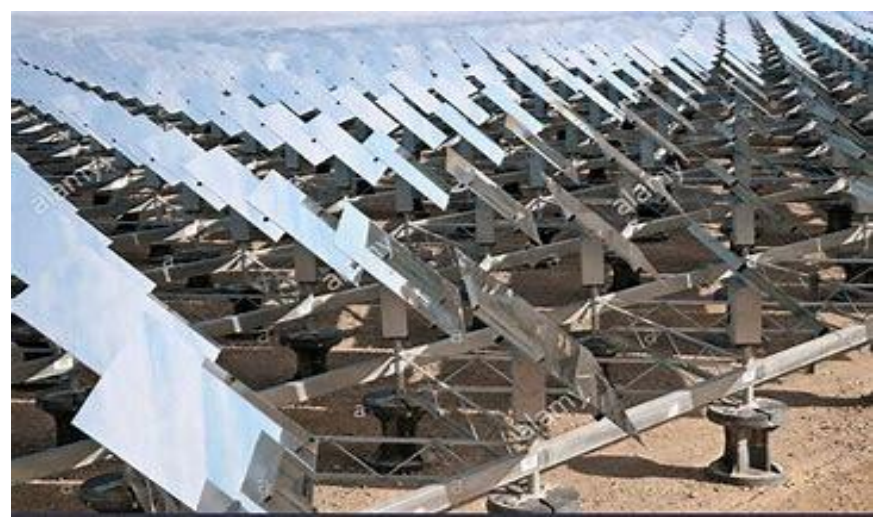

Figure.2. Heliostat at Solar Tower

\subsection{Receivers in Solar Tower:}

The receiver is one of the most essential parts of solar tower plants. Generally, there are two types of receivers: volumetric and tubular. Volumetric receivers use air or supercritical carbon di-oxide $(\mathrm{CO} 2)$ as heat transfer fluid and tubular receivers are used for liquid heat transfer fluid such as water, thermic oil, molten salt, Hitec salt and liquid sodium.The type of receiver depends on the type of power cycle (Brayton or Rankine) and HTF (Heat Transfer Fluid) used in the system.

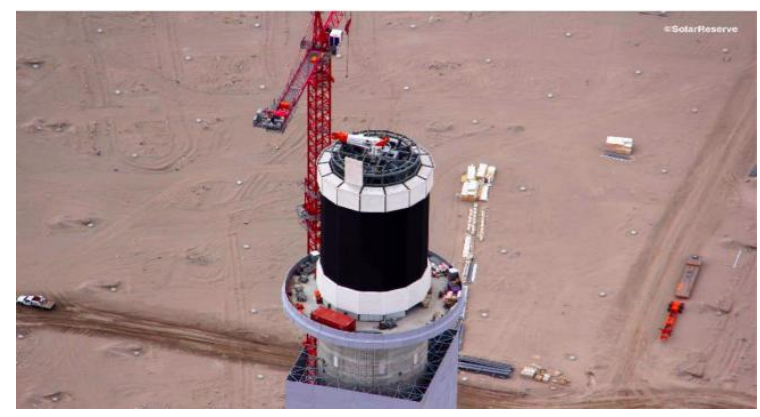

Figure.3. External Tubular Receiver 
In tubular receivers, the heat transfer fluid passes through numerous vertical tubes and gets heated by the radiation reflected from the heliostats. Generally, there are two types of tubular receivers:

1. Cavity receivers and

2. External cylindrical receivers.

In External cylindrical receivers vertical tubes are arranged side by side, in a cylindrical manner and the radiation from the heliostats converges from all directions. The cavity receivers consists of Welded tubes placed inside a cavity orvacuum to avoid Convection losses by eliminating physical contacts.[5-8]

\subsection{Heat Transfer Fluid:}

Based on the power cycles and type of receiver, different types of Heat Transfer Fluids can be employed in the system. The heat transfer fluids used in the operational solar towers are molten salt, water, and air. In order to use water, it requires a heat exchanger which can give a output temperature of range $250^{\circ} \mathrm{C}$ and $566^{\circ} \mathrm{C}$. In case of Molten Salt, The heat is transferred to the water then Steam is generated through which a temperature of $258^{\circ} \mathrm{C}$ can be obtained. Volumetric Type receivers uses air as heat transfer fluid.Air at higher temperatures over $1000^{\circ} \mathrm{C}$ gives rise to high rate of heat transfer properties but the pipes carrying the heat transfer fluid is to be considered.

\section{Rankine cycle}

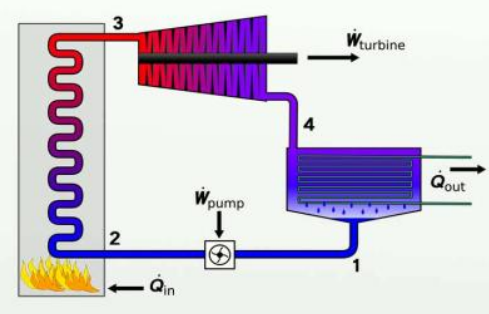

Figure.4. Rankine Cycle of Solar Tower

\subsection{Power Cycle:}

One of the most important component of the plant is the power block. The solar energy collected by the receiver is converted to a usable form of electrical energy. The two main power cycles used in solar tower plants are discussed in the following.

\subsubsection{Rankine Cycle:}

In the Rankine Cycle, water is the working fluid where the water is converted into Steam which is used to run the Turbines. After passing through the Turbine, the steam attains low pressure which is condensed and passed as high pressure fluid again to the tank using a pump.

\subsubsection{Brayton Cycle:}

The Brayton cycle has the similar processes as the Rankine cycle. It does not operate within the vapour dome. It operates at higher temperature and pressure.Generally, the working fluid used here is compressed gas. The carbon di-oxide Brayton cycle is being explored for solar tower technology and it is under Research \& Development mode.

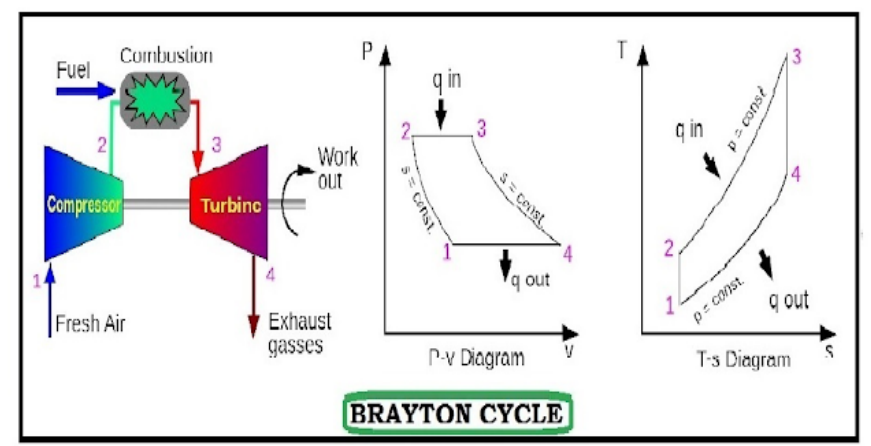

Figure.5. Brayton Cycle of Solar Tower

Table.1

MERITS \& DEMERITS OF HEAT TRANSFER FLUID USED IN SOLAR TOWER PLANTS [8-12]

\begin{tabular}{|c|c|c|c|}
\hline S.NO & $\begin{array}{c}\text { HEAT } \\
\text { TRANSFER } \\
\text { FLUID }\end{array}$ & MERITS & DE-MERITS \\
\hline 1. & WATER & $\begin{array}{l}* \text { For steam } \\
\text { Rankine cycle, } \\
\text { working fluid is } \\
\text { the water, the } \\
\text { necessity for } \\
\text { heat exchanger } \\
\text { is eliminated. } \\
\text { *Reduces } \\
\text { the costs } \\
\text { associated with } \\
\text { the salt or oil } \\
\text { based Heat } \\
\text { Transfer Fluids. }\end{array}$ & $\begin{array}{l}\text { *Dissimilar } \\
\text { heat transfer } \\
\text { coefficient in } \\
\text { saturated } \\
\text { vapour, } \\
\text { superheated } \\
\text { gas phase and } \\
\text { liquid.Frequent } \\
\text { problems with } \\
\text { thermal stress } \\
\text { and } \\
\text { temperature } \\
\text { gradient to be }\end{array}$ \\
\hline
\end{tabular}




\begin{tabular}{|c|c|c|c|}
\hline & & & $\begin{array}{l}\text { faced. } \\
* \text { As the } \\
\text { solar flux } \\
\text { varies } \\
\text { problems arise } \\
\text { with Flow } \\
\text { control. } \\
\text { *Thermal } \\
\text { storage is } \\
\text { difficult for } \\
\text { long time. }\end{array}$ \\
\hline 2. & $\begin{array}{c}\text { MOLTEN } \\
\text { SALT } \\
\text { (KNO3 + } \\
\text { NANO3) }\end{array}$ & $\begin{array}{l}\text { *High } \\
\text { Thermal } \\
\text { conductivity } \\
\text { and capacity. } \\
\text { * Operating } \\
\text { Temperatures } \\
\text { can rise up to } \\
560^{\circ} \text { C. } \\
\text { *Stable and } \\
\text { Non-Toxic \& } \\
\text { Environment } \\
\text { Friendly. }\end{array}$ & $\begin{array}{l}* \text { Auxiliary } \\
\text { heating is } \\
\text { required in } \\
\text { order to avoid. } \\
\text { solidification } \\
\text { at high melting } \\
\text { point }\left(222^{\circ} \mathrm{C}\right) \text {. } \\
* \text { At elevated } \\
\text { temperature it } \\
\text { is highly } \\
\text { corrosive. }\end{array}$ \\
\hline 3. & Air & \begin{tabular}{l}
\multicolumn{1}{c}{ *High } \\
Temperature \\
over $1000{ }^{\circ} \mathrm{C}$ \\
can be used.
\end{tabular} & $\begin{array}{l}\quad \text { *Compared } \\
\text { to other fluids } \\
\text { it has Poor } \\
\text { heat transfer } \\
\text { properties and } \\
\text { complex } \\
\text { receiver } \\
\text { design. }\end{array}$ \\
\hline 4. & $\begin{array}{l}\text { Liquid } \\
\text { sodium }\end{array}$ & $\begin{array}{l}\text { * Solar field } \\
\text { outlet } \\
\text { temperatures } \\
\text { are high } \\
\text { which results } \\
\text { in higher } \\
\text { power cycle } \\
\text { efficiencies. } \\
\text { *Low } \\
\text { Melting Point } \\
\left(97.7^{\circ} \mathrm{C}\right) \& \\
\text { High boiling } \\
\text { point } \\
\left(873^{\circ} \mathrm{C}\right) .\end{array}$ & $\begin{array}{l}\quad * \text { Difficult } \\
\text { in handling. } \\
\quad * \text { Accidental } \\
\text { Leakage may } \\
\text { result in } \\
\text { highly } \\
\text { hazardous } \\
\text { condition. }\end{array}$ \\
\hline 5. & Hitec salt & $\begin{array}{l}\quad * \text { Melting } \\
\text { point is } 142^{\circ} \\
\text { C. }\end{array}$ & $\begin{array}{l}* \text { Temperature } \\
\text { is restricted to } \\
\text { less than } 535^{\circ}\end{array}$ \\
\hline
\end{tabular}

\begin{tabular}{|c|l|l|l|}
\hline & & & $\mathrm{C}$. \\
\hline 6. & & ${ }^{*}$ Freeze at & $*$ Operating \\
& & $15{ }^{\circ} \mathrm{C}$. & temperature \\
& & restricted to \\
& Synthetic & & $390^{\circ} \mathrm{C}$ which \\
& & & results in \\
& & & reduced power \\
& & & cycle \\
& & & efficiency. \\
\hline
\end{tabular}

\section{ADVANTAGE OF SOLAR POWER TOWER}

\subsection{Environmental Neutrality:}

Compared to other forms of renewable energy, solar towers have a negligible effect on the environment.

\subsection{Easy to Operate:}

One major advantage of solar towers are easy to implement compared to many other forms of energy generation.

\subsection{Renewable Energy:}

Additional advantage of solar towers over other conventional means of energy production is that it is a renewable form of energy, while others are not.

\subsection{Falling Costs:}

Solar towers are getting cost effective day by day. A report from the National Renewable Energy Laboratory estimated that by 2020 the levelized cost of energy produced by solar towers could be as little as 5.47 cents per $\mathrm{kWh}$.

\subsection{Predictable, 24/7 Power:}

Solar Thermal Energy can produce power 24 hours a day. This is possible as solar thermal tower store the energy in the form of heat transfer fluids.

\subsection{No Fuel Cost:}

Solar Thermal Energy does not require any fuel 
like other sources of energy. This is a huge advantage over fossil fuels whose costs are increasing at a exponential rate every day.

\subsection{System Benefits:}

The availability of an inexpensive and efficient energy storage system may give power towers a competitive advantage.

Table provides a comparison of the predicted cost, performance, and lifetime of solar-energy storage technologies for hypothetical $200 \mathrm{MW}$ plants.

Table.2.Comparison of Solar-Energy Storage System

\begin{tabular}{|l|l|l|l|l|}
\hline & $\begin{array}{l}\text { Cost of } \\
\text { energy } \\
\text { storage } \\
\text { installed } \\
\text { of 200 } \\
\text { MW } \\
\text { plant( } \square / \mathrm{K} \\
\mathrm{W} \text { hrs) }\end{array}$ & $\begin{array}{l}\text { Life- } \\
\text { Span } \\
\text { of } \\
\text { Stora } \\
\text { ge } \\
\text { Syste } \\
\text { m } \\
\text { (year) }\end{array}$ & $\begin{array}{l}\text { Round } \\
\text { Trip } \\
\text { Storage } \\
\text { efficien } \\
\text { cy } \\
(\%)\end{array}$ & $\begin{array}{l}\text { Maximum } \\
\text { operating } \\
\text { Temperat } \\
\text { ure }\end{array}$ \\
$\left({ }^{\circ} \mathrm{F}\right)$
\end{tabular}

\section{Fresnel Lens:}

A Fresnel Lens is a category of Composite compact lenses. A Fresnel lens can be made thinner than a comparable conventional lens. The construction of Fresnel lenses of large aperture and short focal length which results in reduced mass and volume of material that would be required by a lens of conventional lens. It can capture more oblique light from any light source.

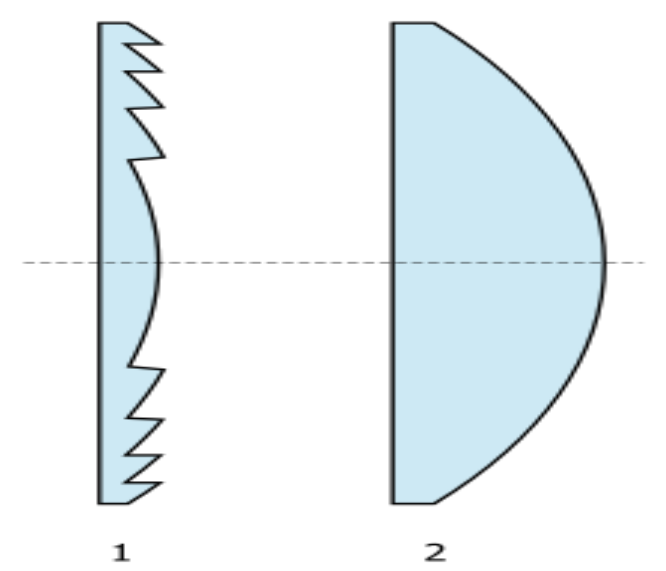

Figure.6:Cross-sectional of Fresnel lens Fig 7:Cross-sectional of conventional spherical lens

An ideal Fresnel lens would have a numerous sections. They are made up of glass. Modern Fresnel lenses usually consist of almost all refractive indices. Their size varies from large to small. In most cases there are very thin and flat, almost flexible, around thickness of range 1 to 5 $\mathrm{mm}$.

\subsection{Types of Fresnel Lenses:}

Mainly there are two types of Fresnel lens: imaging and non-imaging. Non-imaging lenses have segments with flat cross-sections, and do not give sharp images while imaging Fresnel lenses use segments with curved cross-sections which give sharp images. As the number of segments increases, the two types of lens become more similar to each other. In the abstract case of an infinite number of segments, the difference between curved and flat segments disappears.

\subsection{Fresnel lens in Solar Power:}

Plastic Fresnel lenses can be made larger than glass lenses, and also much cheaper and lighter. They can be used to generate steam or to power a Stirling engine. Fresnel lens can be also used to concentrate sunlight for heating in solar cookers, in solar dryer, and in solar collectors used to heat water for domestic use \& commercial use. Fresnel lenses concentration ratio to single solar cell is almost 500:1. This allows the active solar-cell surface to be reduced more than desired rate and also lowering cost along with allowing the use of 
more efficient cells.

\section{Ball Shaped Solar Tower:}

Solar Tower is an emerging concept and environmental heating in that is the major disadvantage. Environmental Heating can be overcome by a new concept of solar lensballs. The Fresnel lens are used as a Focusing material to focus the sun's radiation on a particular spot where receiver can be placed. The Fresnel lens are arranged in a pentagonal structure as shown in the CAD model to achieve maximum concentration of the sunlight. The Maximum Temperature at the focal length point is $400^{\circ} \mathrm{C}$ at peak sunshine. The Fresnel lens focusses the sunlight on the absorber tube with a focal length of $100 \mathrm{~mm}$.

The Area of a Pentagonal Fresnel Lens is about $0.1 \mathrm{~m}^{2}$. By the formula for Area of Pentagon mentioned below, the sides of the Pentagon is found to be $0.241 \mathrm{~m}$.

Area of the Pentagon $=\frac{1}{4} \sqrt{[5(5+2 \sqrt{5})]}$ a $a$

Where a-stands for Side of a Pentagon. It contains 10 Pentagon of $0.1 \mathrm{~m}^{2}$. So totally the area of the Structure is around $1 \mathrm{~m}^{2}$. It can Focus Sun's Radiation from all the direction and thus maximum Thermal Energy can be harvested.

\subsection{Model View using Fusion 360:}

The Design of the ball-shaped tower is drawn using Fusion 360 and mentioned below:

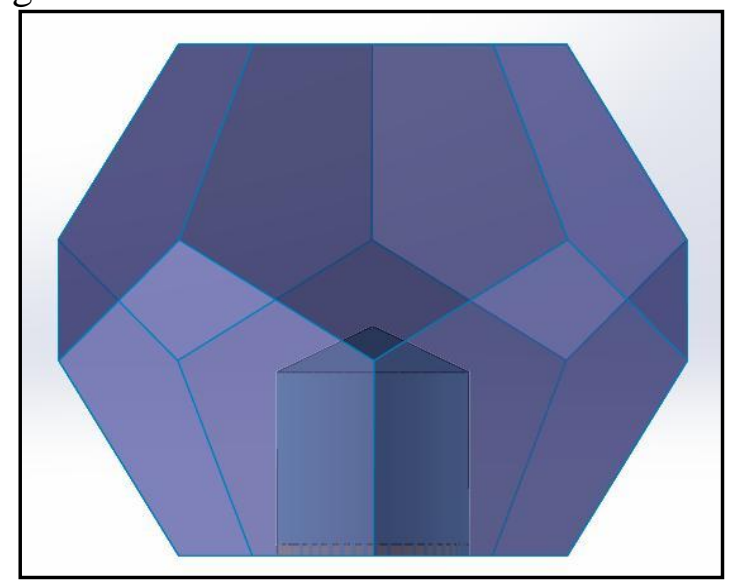

Fig.8. Front View

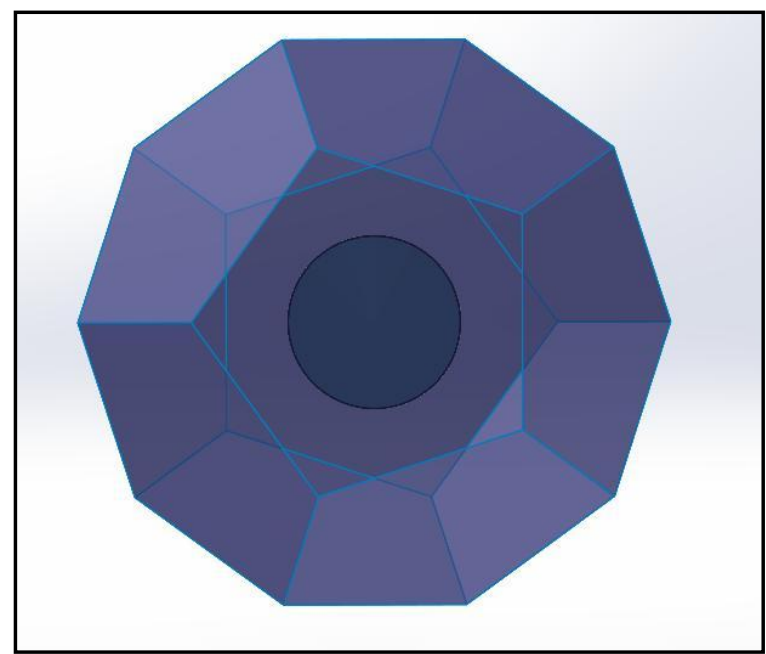

Fig.9.Top View

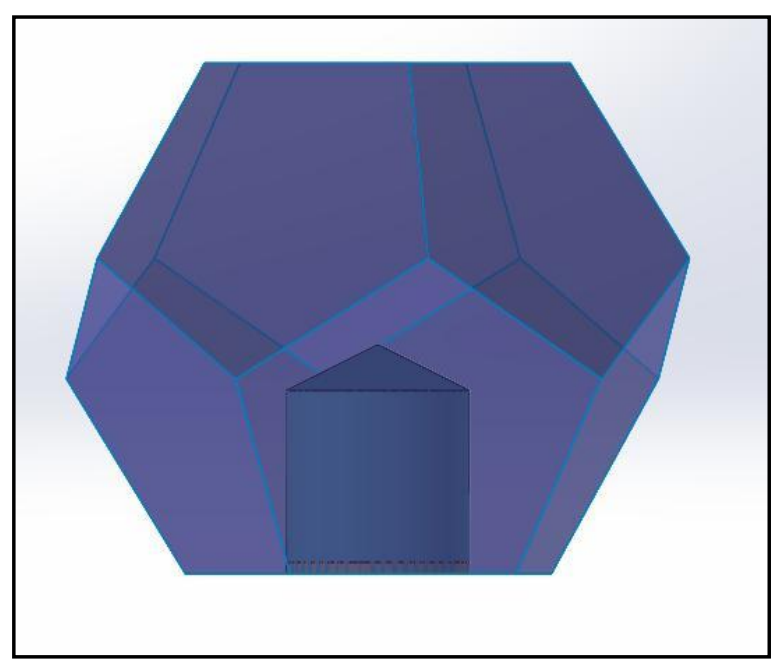

Fig.10.Side View

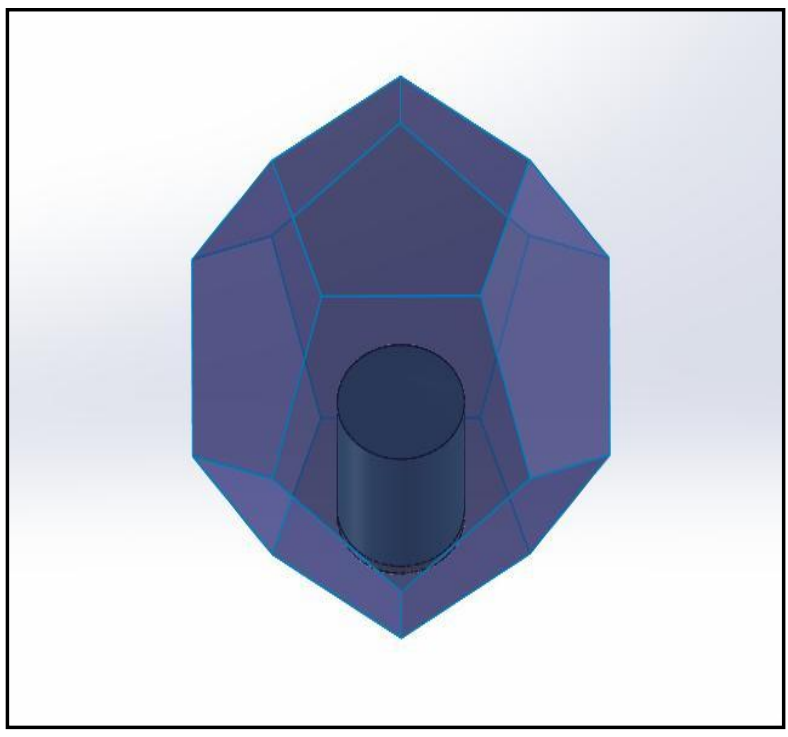

Fig.11.Orthogonal View 
www.rspsciencehub.com

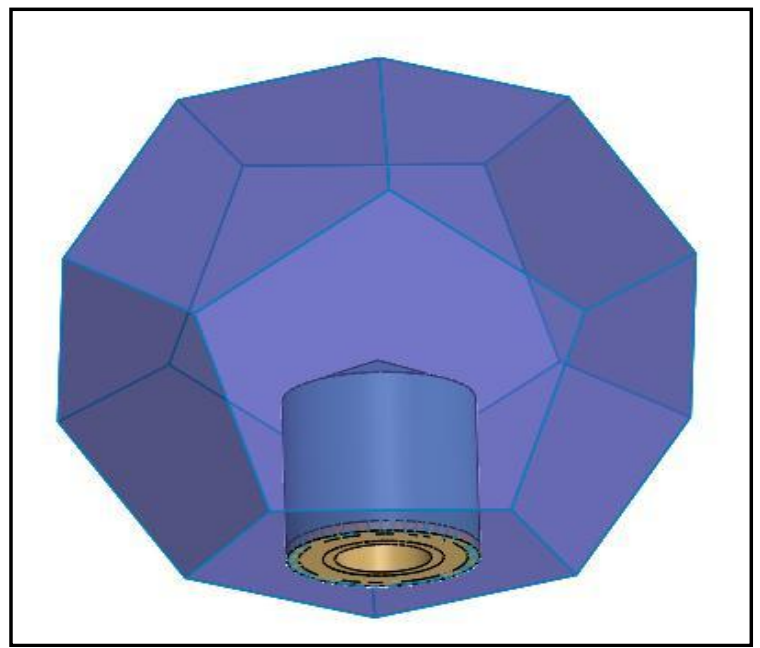

Fig.12.Orthogonal View

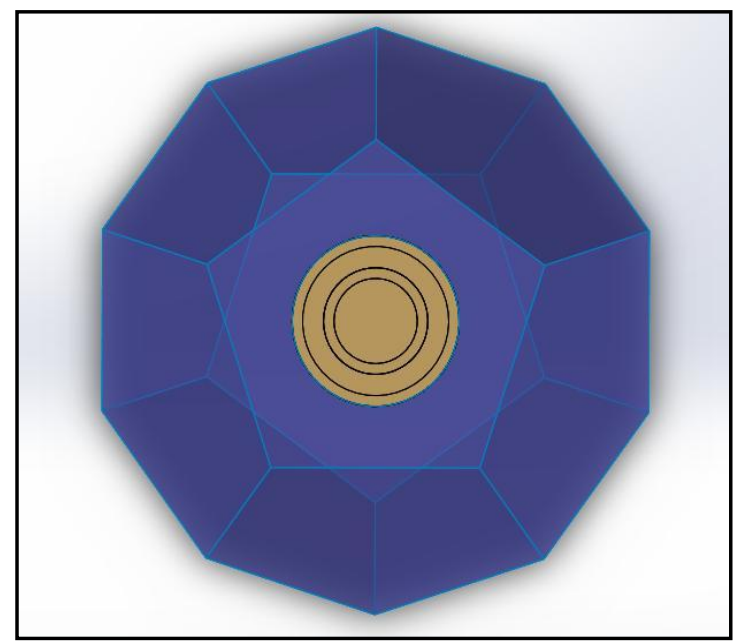

Fig.13.Bottom View

\section{Conclusion \& Future Work:}

Here, The Solar energy is converted into Thermal Energy without involving any intermediate conversion state. This can be developed as mentioned below:

1. It can be used in Home appliances such as Solar Cooker and Solar Water Heater.

2. Huge Plants can be built, thus large amount of energy can be stored and consumed.

\section{References}

[1] Hugh E. Reilly et al Evaluation of Molten salt power tower including Result of the solar two Project" November 2001.

[2] Reiner Buck et al"Dual-receiver concept for solar towers" 2 March 2005. | 21 September 2011.

[3] Chao Xu et al "Energy and exergy analysis
Volume 02 Issue 07 July 2020

of solar power tower plants" 24 july 2011.

[4] SpirosAlexopoulos et al "Solar tower power plant in Germany" 8 September2009. |

[5] www.google. com \&www.wikipedia.com

[6] A. Ramos a et al Strategies in tower solar power plant optimization” 22 May 2012.

[7] "Solar Power Tower" by Prof. Chandan Kumar \& Gaurav Kumawat

[8] "Global Review of Solar Tower Technology" by Thirumalai N C

[9] R. Ben-Zvi et al "Simulation of an integrated steam generator for solar tower" 1 November 2011.

[10]Solar tower power plant optimization: a reviewTechnical Report - November 2016 DOI: 10.13140/RG.2.2.13416.78088

[11] Akiba Segal and Michael Epstein"The optics of the solar tower reflector" 13 September 2000.

[12]A Alex, RS Kumar, A Comparative Analysis of THD in Fuzzy Controller based Symmetric and Asymmetric Multilevel Inverter', International Electrical Engineering Journal 4 (1), 946952 